date on the evidence of the plant-remains found in the coal seams which are associated with it.

Owing to the difficulty of determining questions of relative superposition in a country so densely clothed with vegetation, and to the insignificant depth of the sections, natural and artificial, which are accessible, coupled with the remarkably disturbed condition of lare tracts of the sedimentary rocks-it is not possible to define at present the relations of the igneous to the sedimentary rocks of the district. Neverheless, such evidence as I have myself been able to collect goes to supuort the hypothesi ; that the last outbreak of volcanic activity was posterior in date to all but the more modern deposits of shales, clays, river.gravels, \&c., or, in other words, that it preceded more or less immediately, the last submergence of north-west Borneo-though separated from that submergence by a long interval, and possibly being the concomitant of an antecedent elevation of the land.

The traces of this outbreak retsain in the existence of thermal springs, two at least of which occur in association with hills of trappean and basaltic rocks; the country in many parts is dotted with hills of basalt, columnar basalt, and felspathic porphyries, and in the intervening lowlands is seamed with dykes of porphy. ritic, hornblendic, and silicecus rocks ; the sedimentary strata are greatly disturbed when the igneous rocks occur, being often upheaved at high ang!es and much plicated, and locally the sandstones and shales have been metamorphosed; whilst masses of a volcanic-conglonerate (?) are occasionally met with.

Philippine Islands, September 27

A. H. EVERETT

\section{New Form of Telephone}

Having had the pleasure of listening to Mr. Preece and Prof. Graham Bell explaining that most wo derful invention, the telephone, at the late meeting of the British Association in Plymouth, I endeavoured to obtain the instrument for my own use, and was ultimately successful.

It soon struck ine that if the disc or diaphragm whose vibration cau ies the induced current in the coil of copper wire must be a magnetic substance, and not simply a conducior, then if -I could succeed in getting an electrimagnet to vibrate in a similar manner it might be possible to get as powerful a sound.

With this object in view a coil of insulated copper wire was fastened to a card, as shown in Fig. $I$.

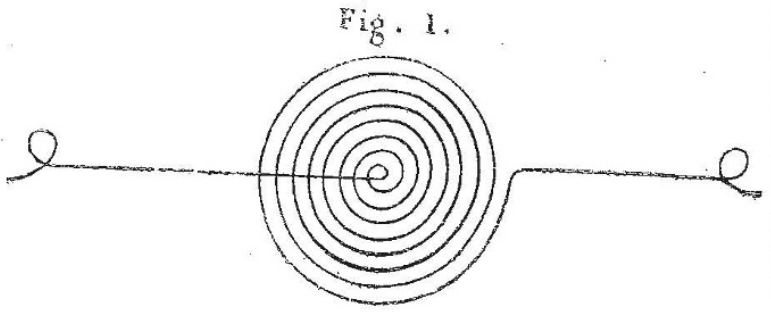

The wire used was No. 28 cotton ${ }^{2}$ covered, and it was sewed to the card with thread.

The iron disc was taken out of one of the telephones, and the coil-diaphragm put in its place through which a current was passed from a sirgle Bunsen cell. On making connection with the other telepbone, talking, singing, and whistling were heard distinctly at both.

Various coils have since been tried both with thicker and also thinner wire, but as yet the results have not been as good as when the iron $\mathrm{d}$,sc is used.

When two such coils are used, one superposed on the other, the loudness of the sound transmitted is increased to some extent. The same result is produced by adding another Bunsen cell. With a Danieli's cell the suund is very feeble. When a coil is placed in each telephone the result is rather unsatisfactory as yet.

It has also been noticed that a simple conductor as a coil of copper wire a so transinits sound but very faintly.

A small apparatus (Fig. 2) has been made to show the effects above described. A piece of wood about three inches square and about one inch thick has a hole bored through it about two inches in diametcr. A reel (2) containing about 250 yards of silk-covered copper wire is placed in the hole with a piece of soft iron about lialf an inch in dianneter as axis (I).

A coildiaphragm (3) is placed across one end of the hole at a very short distance from the soft iron core, and is covered by a mouth-piece. Across the other end of the hole at a similar dis. tance from the core is placed a thin iron disc (4) which is also covered by a mouth-piece. On a current being passed through the coil-diaphragm this apparatus acts as a telephone, and messages can be sent from either side of it.

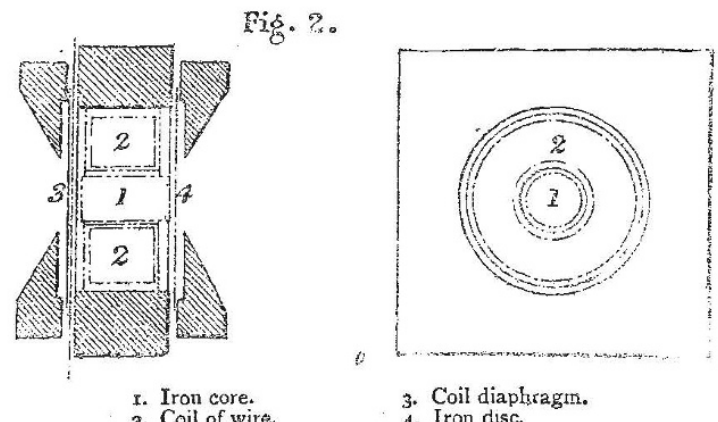

The iron disc and core may be removed, and the coile diaphragm alone acts in an exactly similar manner.

The above are the results of some experiments which have occupied my spare time lately, and not having seen anything similar published I forward them to you as they are rather interesting. The whole of the experiments have been conducied with the aid of my friend, Mr. G. B. Nicoll, who has also made many impurtant suggestions:

JAMUS M. ROMANIS

\section{Shooting Stars}

The number of shooting stars seen here during the last six months (July to Decemb-r) is 2,259 in 168 hours of watching. This number includes 385 Perseids observed between August 3 and 16 . Of the remaining $1,874,1,028$ were seen during seventy. five hours in the mornings and 846 during ninety-three hours in the eveningss. After making certain allowances for time spent in registering the paths (and omitting the Perseids), the horary numbers appear to have been as follows :-

$$
\text { I6.4 A.M., } 10.9 \text { P.M., } 13.4 \text { A.M. and P.M. }
$$

From these figures I estimate that the aggregate number of shooting-stars as bright as, or brighter than, 5 th mags., which entered the earth's atmosphere in this particular part of the world by night and day during the last six months, was about 236,700 . The horary number has already been mentioned as 134 ior one observer. Now a single pair of eyes certainly cannot command more than a fourth part of the visible sky, so that we must adopt $53^{\circ} 6$ as the horary rate over the whole sky. From this we readily deduce the diurnal number as $1286^{\circ} 4$, and the aggregate for the six months, $236,697^{\circ} 6$ as above.

When it is further considered that the averaye height of ordi. nary shooting-stars is only about seventy miles, and that therefore observers at widely distant stations must each see a distinct set altogether, we are able to form some remote idea of the vast number that enter our atmosphere every day.

Bristol, December 26, 1877

\section{W. F. DENNING}

\section{Gentiana asclepiadea and Bees}

THIs gentian is very abundant on the mountain slopes round Engelberg, as visitors to that parto Switzerland well know. As I was botanising in the neighbourhood, in the autumn of this year, I observed that most of the flowers were pierced with a round hole at the base. Presently I saw a bee come to one of the pierced flowers, and thrust in its proboscis in search of honey. The flowers of this beautiful, sweet-smelling gentian are long and funnel-shaped, and very contracted at the base, and, as the bee that visied it was a "fair large" one, like Sir Torre's diamond, and not of the narrow hive-bee type, it could not possibly have effected its purpose by entering the flower in the usual way at the rop, and had no doubt resorted to this method of extracting the honey. I only saw this one kind of bee visit the flowers, but I saw many of them at work, and all acted in the same way. One of them came to some of the flowers, which I had gathered, as I held them in my hand. I cannot say that I saw a single fluwer ac ually pierced by a bee; the day was warm, even for Engelberg, and the bees were very 